Issued twice yearly by the Tyndale Fellowship for Biblical Research, Tyndale House, Selwyn Gardens, Cambridge.

Price to non-members : 1s. 3d. per copy, post free.

No. 2 .

WiNTI:R, I956-7

Page

A recently published Egyptian papyrus and

its bearing $\mathrm{c} n$ the Joseph story ... K. Kitchen $\quad$ I

The Death of Stephen $\ldots$... $\quad \ldots \quad$ P. A. Blair 2

The Ground of Justification … ‥ B. G. Felce 4

More Unpublished Hymns by Charles ...

$\begin{array}{lllllll}\text { Wesley } & \ldots & \ldots & \ldots & \ldots & \text { J. Dale } & 5\end{array}$

$\begin{array}{llllll}\text { Notes and News } & \ldots & \ldots & \ldots & 6\end{array}$

\title{
A RECENTLY PUBLISHED EGYPTAN PAPYRUS AND ITS BEARING ON THE JOSEPH STORY.
}

An important Egyptian hieratic papyrus has been published recently in Imerica. The contents of the papyrus and the specialist nature of the book make it worth while to outline here the value of this new material for Old Testament background.

This document is Papyrus Brooklyn 35.1446, excellently published by IV. ( $:$ Hayes, A Papyrus of the Late Middle Kingdom in the Brooklyn Museum 1955 It is part of the Register of Criminals of the Great Prison at Thebes, current for years 10 to 3 I of the I2th Dynasty Pharaoh Amenemhat III about $1833^{-1}-1212$ B.C. Some sixty years later, in Dynasty XIII, the reverse of the nutdated Register was utilised for a list of seventy-nine servants in a large ligyptian household, forty-five of these being Asiatics, mainly Semites--apparenily sold into Egypt as Joseph was to be. The Register was in use only ahout as century before Joseph (ca. 1700 B.C. onward), and the list was made unly to years or so before his time. We thus have new background material fir J mpph's uslavement and imprisonment in Egypt.

In Fon an law-codes like those of a Lipit-Ishtar or a Hammurabi of Mesputarnio hav yet been found, although we know they once existed; and the lops uru khenrel, "Laws of the Prison" are mentioned in one texti at feitst (Dnly examples of 'law applied' in the form of actual wills, depositions, erc., and some supplementary edicts of King Haremhab (ca. I320 B.C.) have tas yer w..me to light. The new papyrus makes possible reference to five clasises of definitive law.

In Dynasties XII-XIII (Middle Kingdom) and XVIII (New Kingdom). the ligyptian l'risun system is known only from hints in inscriptions of etficials and in papyri, especially now the Brooklyn document. Hayes (pp. 37-40) has surveyed concisely and well our present knowledge in this field. iiesides being a criminal 'lock-up', an Egyptian prison was also a labour camp for peasants on state corvejes, escape from which service constituted a criminal uffence. In the prisons, Egyptian criminal records (like Brooklyn Papyrus) were maintained. A "Criminal Register in the Great Prison" is mentioned in a text of the famous Dynasty XVIII Vizier Rekhmire. The "Great Prison" (khenret weret) was at Thebes; others may have been located at Memphis and Heliopolis, and every large town probably had its local prison. One was at Ke-hòne (modern Lahun) near the XII-XIII Dynasty capital of Itjet-tawi; perhaps, like Joseph's prison, it received court offenders. Joseph was evidently confined in such a place at the capital where the Court was held in his day, most likely at Memphis.

Various grades of prison staff are attested. At their head was a Direcur' or Governor of a prison (imy-ra-khenret); in Genesis xxxix-xl the captain of the guard seems to excercise this function. The 'Keeper' there 
mentioned was perhaps a subordinate 'Keeper of the Prison' (sa'wly en khenret). In Dynasties XII-XIII 'Scribes of the Great Prison' are especially attested. Hayes cit es six 'Directors', ten 'Scribes' and one 'Keeper' in his book. One oinicial, on British Museum Stela 828, tells how ".......His Majesty made me Scribe of the Prison of Trial", later on "...... Scribe of the Great Prison", and eventually “....Scribe of the Royal Records......". The prisons maintained, as would be expected, close links with the Department for Agriculture and the Labour bureau (literally, 'Office of the Provider of People'), as reflected in the new papyrus.

In the Criminal Register of the Great Prison at Thebes, the Brooklyn Papyrus names seventy-six citizens who had absconded from state corvée or like service. It systematically files each person under seven headings, giving as follows : (1) name; (2) distinguishing epithet; (3) sex; (4) resumé of government directive, citing the charge and calling for proceedings under the appropriate clause of the law code; (5) a note, "Here". or. "Brought", or something similar-i.e., the offender is safely in prison or soon will be; (6) statement of completion of the case from the scribe of the Vizier; (7) a final check-mark, "Case closed". No doubt this final laconic note would conclude the records of the butler, baker and Joseph when they left prison over a century later ! The Egyptian authorities seemed invariably to have tracked down their criminals and to have kept long-standing cases open with dogged persistence.

The verso of the Papyrus is equally intriguing, for it lists seventy-nine servants in a large Dynasty XIII Egyptian household (ca. I745 B.C.) of whom forty-five were (mainly Semitic) Asiatics. A few, especially the children, bear purely Egyptian names, but most bear Semitic names. Nearly forty of these people actually bear a (usually) Semitic name followed by the epithet 'who-is-called' and a second, Egyptian, name. This provides' a powerful contemporary parallel for the construction of Joseph's Egyptian name Zaphenath-Paaneah, (to be the subject of a forthcoming study). One or two names in the Brooklyn list are of special interest. One is identical with the later Hebrew name 'Menahem'. Another is actually a 'Shiphr(ah)', later the name of midwife in Ex. i: 15, who thus bore in her time a name already venerable. A third is etymologically comparable with that of Job. The status of some of these servants is a perfect reflection of Joseph's first status in Potiphar's household. In Gen. xxxix. 2, Joseph is a domestic servant 'in the house'-exactly the status hery-per recorded of Semites and Egyptians in the Brooklyn Papyrus and elsewhere. (Note that this is not an exalted title as Yahuda claimed.) Later, in Gen. sxxix. 4, Joseph rose to be Steward in the household, the very common Egyptian title of imy-ra-per.

Although neither main portion of this papyrus directly touches Joseph himself, yet its fascinating background material contributes forcefully to the impression of reality in Gen. xxxix-xl.

School of Archaeology

and Oriental Studies,

K. A. KITCHEN.

University of Liverpool.

\section{THE DEATH OF STEPHEN}

The prominent position given by Luke to Stephen's speech in Acts vii is acknowledged by all. So is its connection with Saul's conversion, which is hinted at in vii. $5^{\delta}$. But it is possible that the formal connection made in viii. I between ch. vii and the events of ch. viii covers a very much deeper and larger conception in Luke's mind than is generally realised: that these two chapters with their continuation in ch. ix and onwards draw out the full significance of the death of Christ for all men, not simply as a forecast of the future but as a practical reality.

The starting point of this investigation must be the charge preferred against Stephen. In vi. I I the suborned men accuse Stephen of speaking against the Law; in vi. $13 \mathrm{f}$. the charge is expanded, and the parallel with Jesus made explicitly: (R.S.V.)

"This man never ceases to speak words against this holy place and the Law."

"Jesus of Nazareth will destroy this place, and will change the customs which Moses delivered to us." 